\title{
The development of sex differences in ring-tailed lemur feeding ecology
}

\author{
M. Teague O’Mara • Cathriona M. Hickey
}

\begin{abstract}
Sex differences in feeding ecology may develop in response to fluctuations in physiological costs to females over their reproductive cycles, or to sexual size dimorphism, or function to minimize feeding competition within a group via resource partitioning. For most mammal species, it is unknown how these factors contribute to sex differences in feeding, or how the development of males and females reflects these intraspecific feeding differences. We show changes in dietary composition, diversity, overlap, and foraging behavior throughout development in ring-tailed lemurs (Lemur catta) and test how the development of sex differences in feeding is related to female costs of reproduction and year-round resource partitioning. Sex differences in dietary composition
\end{abstract}

Communicated by M. A. van Noordwijk

Electronic supplementary material The online version of this article (doi:10.1007/s00265 0141738 3) contains supplementary material, which is available to authorized users.

\section{T. O’Mara}

Smithsonian Tropical Research Institute, Panamá, Panamá

\section{T. O'Mara}

School of Human Evolution and Social Change, Arizona State University, Phoenix, USA

\section{T. O’Mara}

Zukunftskolleg and Department of Biology, University of Konstanz, Konstanz, Germany

\section{T. O’Mara $(\bowtie)$}

Department of Migration and Immuno Ecology, Max Planck Institute for Ornithology, Am Obstberg 1,

Radolfzell 78315, Germany

e mail: tomara@orn.mpg.de

C. M. Hickey

CIRCLE, Environment Department, University of York, York, UK were only present when females were lactating, but sex differences in other aspects of feeding, including dietary diversity, and relative time spent feeding and foraging, developed at or near the time of weaning. Sex difference in juveniles and subadults, when present, were similar to the differences found in adults. The low year-round dietary overlap and early differences in dietary diversity indicate that some resource partitioning may begin with young individuals and fluctuate throughout development. The major differences between males and females in dietary composition suggest that these larger changes in diet are closely tied to female reproductive state when females must shift their diet to meet energetic and nutritional requirements.

Keywords Behavioral development $\cdot$ Diet $\cdot$ Juvenile $\cdot$ Female dominance $\cdot$ Reproduction $\cdot$ Resource partitioning $\cdot$ Lemur catta

It is often expected that individuals within a population of different ages, sexes, and sizes, will exploit varying aspects of the species' feeding niche (Schoener 1986; Ebenman 1988). As part of this variation, sex differences in vertebrate feeding can range from temporal and spatial separation of males and females (Ruckstuhl and Neuhaus 2002; Ruckstuhl 2007) to differences in the composition and diversity in diet (CluttonBrock 1977a; Holmes 1986; Clarke et al. 1998; Lewis et al. 2002; Beck et al. 2005; Krüger 2005). For most species, however, little is known about when sex differences appear, how they change throughout development, if early sex differences mimic adult patterns, and if these sex differences function to partition resources or are only apparent with physiological differences between males and females, particularly those related to reproduction.

The successful development of ecological competence and adult diet is the primary determinant of whether individuals 
live to adulthood and their subsequent reproductive success (Altmann 1991, 1998). In species with few sex differences in adult foraging (Post et al. 1980; Harrison 1983), sex differences are expected to be closely correlated with female reproductive status (Gautier-Hion 1980), and no sex differences are expected to be found in juveniles (van Noordwijk et al. 1993). Likewise, juveniles of species with large and distinct adult sex differences in dietary composition or foraging strategy (Terborgh 1983; Fragaszy 1990; Lonsdorf 2005), which are often species with large degrees of sexual size dimorphism, will show similar patterns of sex differences in adults regardless of female reproductive stage. The persistence of sex differences in feeding outside of periods of high reproductive costs to females can be socially learned through same-sex modeling (Agostini and Visalberghi 2005; van de Waal et al. 2013), and sex differences in attention span and learning may contribute to the development of female and male feeding ecologies (Lonsdorf et al. 2004; Lonsdorf 2005). Developmental differences in size, strength, and coordination can also determine differences in female and male foraging strategies (Rose 1994; Johnson and Bock 2004; Gunst et al. 2008, 2010). These interactions between the social environment and somatic growth suggest that the development of sex differences in feeding can be a complex process, but understanding how feeding behaviors and diets develop will help illustrate how young animals develop in sex-specific roles, how this development reflects the adult ecology, and if these differences in adult ecology reflect physiological changes or other potential social manipulation.

Sex differences in feeding can be a result of sexdependent physiological costs, competition, and social dynamics (Clutton-Brock 1977a; Ruckstuhl 2007), and the developmental timing of the type and intensity of sex differences in feeding can help identify underlying causation. Sex differences in adult feeding are commonly linked to fluctuations in energetic and nutritional needs associated with sexual size dimorphism and costs of reproduction to females. Size dimorphism can have far reaching effects on growth, metabolism, and substrate or microhabitat use, as well as an individual's nutritional demands (Kleiber 1965; Fleagle and Mittermeier 1980; Jarman 1983; McGraw 1998; Beck et al. 2005; O’Mara et al. 2012). If size dimorphism is solely responsible for sex differences in feeding, then the divergence of female and male feeding ecology should parallel the developmental changes in size and strength (Jarman 1983; Watts 1988). However, sexual dimorphism can also determine the priority of access to foods, with the larger or dominant sex more likely to exclude others from desired feeding patches (Jarman 1983; Ménard and Vallet 1986; Wan et al. 2013). Sexbased social dominance can determine priority of access and sex differences in feeding could be imposed through harassment or monopolization by the dominant individuals
(Barton and Whiten 1993; Bonanni et al. 2007), particularly in the absence of sexual dimorphism (Overdorff et al. 2005; White and Wood 2007; Smith et al. 2008).

While sex-dependent dominance and dimorphism can determine priority of access to resources, these biases may not be the best predictors of feeding differences between females and males (Kamilar and Pokempner 2008). Reproductive costs may be more predictive of sex differences in feeding, particularly during lactation when these costs are greatest (CluttonBrock et al. 1989; Altmann and Samuels 1992; Steudel 2000). These costs can structure much of the variation in dietary composition both within and among species, even to the extent that in some sympatric primate species, lactating females have diets more similar to each other than to male group members (Gautier-Hion 1980; Hemingway 1999; Vasey 2002). Pregnant and lactating females often need higher nutrient and energy intake to compensate for the increased metabolic costs associated with reproduction (Trivers 1972; Tilden and Oftedal 1997). These females feed longer and have diets more highly enriched in protein or energy than males (Sauther 1994; Michels 1998; Bean 1999; Nakagawa 2000; McCabe and Fedigan 2007), regardless of their social status.

Often though, sex-specific dietary differences are present throughout the year and cannot be explained by reproductive costs or size dimorphism (Harrison 1983; Boinski 1988; Rose 1994; Kamilar and Pokempner 2008) and may be a form of resource partitioning that lowers feeding competition within a social group (Clutton-Brock 1977a; Bolnick et al. 2002). The development of sex differences early in life can effectively increase the niche width of a species and minimize feeding competition (Clutton-Brock 1977b; Polis 1984; Schoener 1986; Bolnick et al. 2011; Stauss et al. 2012), regardless of the proximate mechanisms responsible. In adults then, sex differences in feeding throughout the year can facilitate the benefits that are conferred by an increased number of individuals within a social group, while at the same time minimize increases in feeding competition. When combined with individual preferences and bias, sex differences may allow for more flexible use of the species' niche (Bolnick et al. 2002, 2003), even if differences among ages, sexes, or individuals are small.

Ring-tailed lemurs (Lemur catta) are an excellent species to study when sex differences in feeding ecology develop, if differences in immatures mirror those in adults, and how sex differences are related to reproductive costs and resource partitioning. The ring-tailed lemur is a monomorphic primate endemic to southwestern Madagascar that lives in multi-male multi-female social groups where females dominate males in all contexts (Jolly 1984; Kappeler 1990). They feed from a diverse diet composed primarily of ripe fruit and leaves, and the inconsistent rainfall of southwestern Madagascar is correlated with unpredictability in resource availability (Dewar and Richard 2007). 
Our goal is to test for sex differences in the feeding ecology of a mixed-longitudinal and cross-sectional sample of ringtailed lemurs from birth through adulthood. We identify when sex differences develop, and how sex differences in the feeding ecology of infants, juveniles, and subadults parallels that of adults. We also test for the contributions of reproductive costs and resource partitioning in structuring the development of sex differences in feeding (Kappeler 1996; Godfrey and Jungers 2002). If sex differences in feeding are primarily a consequence of female reproductive costs, then we predict that the feeding ecology of immature females and males will closely resemble each other until adulthood. Sex differences will be most pronounced when females are lactating and their energetic expenditure is at its highest. Females will direct more aggression at males and subadults during this time to monopolize resources. These differences will then be minimal or absent throughout the rest of the year. If resource partitioning drives sex differences in dietary composition and diversity, we predict that these differences will appear early in development at the time of weaning, and that they will be maintained through adulthood. Adult females will regulate access to resources through aggression directed at males and immatures to maintain low levels of dietary overlap throughout the year.

\section{Methods}

Study site and phenology Data were collected from May 2009 to March 2010 at the Beza Mahafaly Special Reserve (Beza) in southwest Madagascar $\left(23.65647^{\circ} \mathrm{S}, 44.62897^{\circ} \mathrm{E}\right)$. The study area grades from dry deciduous and Dideraceaedominated desert spiny forest in the west to a gallery forest dominated by Tamarindus indica in the east (Sussman and Rakotozafy 1994). Beza experiences a cold dry season (MaySeptember), and a hot wet season (October-April) in which $80 \%$ of the annual average of $615 \mathrm{~mm}$ of rain falls each year (Lawler et al. 2009). Our study period was hot and dry with average high temperatures of $35.7^{\circ} \mathrm{C}$ (dry season) and $45.8^{\circ} \mathrm{C}$ (wet season) and experienced half the typical rainfall of equivalent times in other years (this study, $265 \mathrm{~mm}$; Beza average for June-March, $500 \mathrm{~mm}$; (Sussman and Ratsirarson 2006)).

Twenty-two $2 \mathrm{~m} \times 30 \mathrm{~m}$ phenology transects were used to monitor the availability of plant resources throughout the ranges of the study groups. Woody plants with a diameter at breast height $(\mathrm{DBH})$ greater than $2 \mathrm{~cm}$ were tagged and identified to species ( $n=402$ individuals from 44 species). The DBH, total height, crown height, and width were measured for each tree. Every 2 weeks, the presence of young leaves and leaf buds, mature leaves, unripe fruit, ripe fruit, flower buds, and flowers was ranked for each tree on a $0-4$ scale based on the abundance of the phase relative to the estimated overall availability of sites within the crown. A score of zero indicated phase absence, $1=25 \%, 2=50 \%$, $3=75 \%$, and $4=100 \%$ present. A $1-\mathrm{m}^{2}$ plot in the center of each transect was used to monitor ground cover with the same phase scale (0-4). A food availability index (FAI) was calculated for each phenophase for each tree within the phenology transects. The FAI is the natural log of each phenophase score (0-4) multiplied by the tree's crown volume. This gives an estimate of availability for each food part based on the size of the individual tree crown and the presence of each part within it.

Study population Ring-tailed lemurs are frugivore-folivores that spend half of their feeding and foraging time on the ground (Sussman 1977). Reproduction is highly seasonal and synchronized to resource availability (Sauther 1991; Jolly et al. 2002). We divided the study period into seasons based on this correlated reproduction and food availability: gestation (May-September), lactation (September-December), weaning (December-February), and recovery (MarchApril) (Fig. 1). All females reproduce annually regardless of social rank, and reproduction is typically timed to a single 1to 2-week period (Sauther 1998), but females who do not conceive cycle again. Therefore some females reproduce out of synchrony with the rest of the group (e.g., gestating in the lactation season), and these females experience different food availability than the majority of females during each reproductive phase. These females are presented separately within each season.

With the help of three field assistants, we completed over 2,300 observation hours on 78 individuals from seven study groups (Table 1). Study groups were composed of between four and six adult females (mode:, 4) and two five males (mode, 3), with a mean female-biased sex ratio of $1.45 \pm$ 0.30. Birth dates were known for the individuals born into each of the study groups since 2006, but birth dates, ages, and matrilineal relationships were not known for females older than 4 years old or for adult males who transfer between groups. We assigned individuals to age classes: infant 1 ( 0 12 weeks), infant 2 (13-24 weeks), juvenile 1 (25 weeks1 year), juvenile 2 (1-2 years), subadult (2-3 years), and adult (3 years and older). Age classes were based on previous work (Gould 1990; Pereira 1995) with subdivision in the infant and juvenile age categories to allow for finer comparisons within these rapidly changing age classes (Pereira and Leigh 2003; Stone 2007; Bezanson 2009; O’Mara 2012). Infant ring-tailed lemurs begin weaning at 8-13 weeks of age (Gould 1990), and the individuals in this sample completed weaning at 24 26 weeks (O’Mara 2012). It is assumed that ring-tailed lemurs are monomorphic throughout development, similar to other closely related lemurid species (Leigh and Terranova 1998; O’Mara et al. 2012). Interobserver reliability was periodically assessed using Cohen's Kappa statistic included in the 
Fig. 1 Food availability index, rainfall, and reproductive seasons. Reproduction is timed to wean offspring at maximum food availability when there is a large flush of young leaves. Note that mature leaves are excluded from the figure, as they are consistently available throughout the year and comprise a small proportion of ring tailed lemur diet

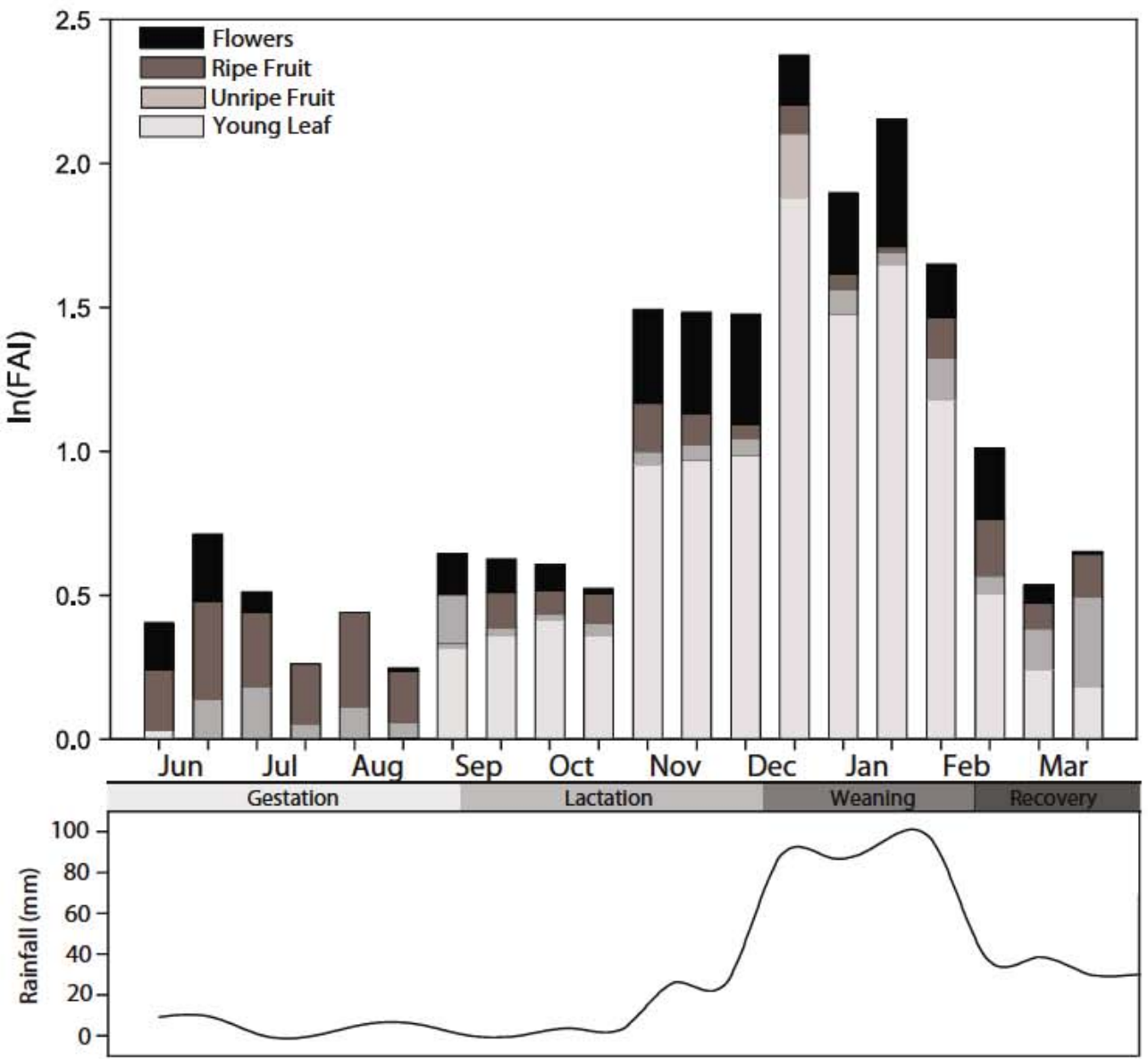

JWatcher package to maintain a $\kappa=0.90 \pm 0.05$ (Coelho and Bramblett 1981).

Data collection Continuous focal sampling (Altmann 1974) was used to record feeding behavior and its social context. Subjects were chosen from among the seven study groups according to a stratified random protocol where an infant or juvenile was the focal subject for every second or third observation. All feeding, foraging, and agonistic behaviors were recorded continuously in JWatcher during 12-min focal animal sampling sessions (FAS). To be included in the analysis, individuals must have contributed a minimum of three FAS in a given day, with individuals contributing between 4 and 8 FAS/day (Table 1).

Feeding was defined as the ingestion of food, and foraging as searching for and processing of food items. Food parts were divided into unripe fruit, ripe fruit, young leaves, mature leaves, flowers and flower buds, invertebrates, soil, and wood. Invertebrates were identified to species when possible and minimally to taxonomic order. Plant species were identified with help of local experts (Mr. Elahavelo and Mr. Herman Mananjo), by Mr. Rokiman Lestara (Tsimbazaza Botanical Gardens, Antananarivo), and through the Missouri Botanical Gardens TROPICOS database (www.tropicos.org). Agonistic encounters during feeding and foraging (aggression and submission given and received) were recorded as events during the focal observation sessions. Here, only aggression that would disrupt feeding and foraging is included (e.g., move to displace, spat, lunge, and cuff; Pereira and Kappeler 1997). Aggression is summarized as the number of aggressive instances over the total time of observation per day to give hourly rates of aggression as well as the number of aggressive behaviors executed minus those received.

Dietary diversity was calculated for each focal animal in 2week periods that correspond to the phenology surveys. Dietary diversity was calculated using the Inverse Simpson's Diversity index, $D$, where $D=1 /\left(\Sigma p_{i}^{2}\right)$ and $p_{i}^{2}$ is the squared proportion of total time feeding in these 2-week blocks on each item (Begon et al. 1996; Irwin 2008). $D=1$ is a diet of 1 item, and higher values reflect increased levels of diversity (Hill 1973). Dietary overlap $(R)$ was calculated for all individual pairs within each group during these 2 -week blocks. $R$ was calculated as $R=\frac{\sum\left(p_{\mathrm{ij}} \times p_{\mathrm{ik}}\right)}{\sqrt{\sum p_{\mathrm{ij}}{ }^{2} \times \sum p_{\mathrm{ik}}^{2}}}$, where $p_{\mathrm{ij}}$ and $p_{\mathrm{ik}}$ are the proportion of item $\mathrm{i}$ in the diet of individuals $\mathrm{j}$ and $\mathrm{k}$ (Pianka 1973). Dietary overlap ranges from 0 (no overlap) to 1 (complete overlap). Bite counts were conducted for each individual on each food type eaten during the 12-min FAS sessions at least twice per 
Table 1 Sample sizes for age sex categories across the repro ductive seasons including nonre productive females ( $\mathrm{F} N \mathrm{NR}$ ), gestating females ( $\mathrm{F}$ Gest), and lactating females ( $\mathrm{F}$ Lact)

Sample sizes are given as number of individuals, total number of hours in italics, with the mean number of hours ( \pm SEM) each individual was observed per day across the study period below. Number of individuals includes animals that have passed from one age category to the next. Blank cells indicate an age sex category that was not observed during the particular season

\begin{tabular}{|c|c|c|c|c|c|}
\hline Age & Sex & Gestation & Lactation & Weaning & Recovery \\
\hline \multirow[t]{4}{*}{ Infant 1} & \multirow[t]{2}{*}{ Female } & & \multicolumn{2}{|l|}{$14 / 93.4$} & \\
\hline & & & $1.02 \pm 0.06$ & & \\
\hline & \multirow[t]{2}{*}{ Male } & & $12 / 93.4$ & $1 / 5.6$ & \\
\hline & & & $1.12 \pm 0.06$ & $1.87 \pm 0.66$ & \\
\hline \multirow[t]{4}{*}{ Infant 2} & \multirow[t]{2}{*}{ Female } & & $8 / 48.8$ & $8 / 36$ & $4 / 17.6$ \\
\hline & & & $0.84 \pm 0.07$ & $1.50 \pm 0.10$ & $1.60 \pm 0.162$ \\
\hline & \multirow[t]{2}{*}{ Male } & & $10 / 60.4$ & $10 / 42$ & $2 / 9.8$ \\
\hline & & & $0.92 \pm 0.07$ & $1.50 \pm 0.14$ & $1.63 \pm 0.21$ \\
\hline \multirow[t]{4}{*}{ Juvenile 1} & \multirow[t]{2}{*}{ Female } & $6 / 112.4$ & $4 / 26.4$ & $6 / 28$ & $4 / 13.4$ \\
\hline & & $1.41 \pm 0.08$ & $2.40 \pm 0.32$ & $1.50 \pm 0.10$ & $1.49 \pm 0.18$ \\
\hline & \multirow[t]{2}{*}{ Male } & $3 / 25.8$ & $1 / 6.4$ & $8 / 22$ & $5 / 14$ \\
\hline & & $1.43 \pm 0.19$ & $2.13 \pm 0.59$ & $1.50 \pm 0.14$ & $1.27 \pm 0.15$ \\
\hline \multirow[t]{4}{*}{ Juvenile 2} & \multirow[t]{2}{*}{ Female } & $3 / 32$ & $6 / 118.8$ & $4 / 17.6$ & $4 / 18$ \\
\hline & & $0.82 \pm 0.08$ & $1.47 \pm 0.09$ & $1.47 \pm 0.18$ & $1.50 \pm 0.25$ \\
\hline & \multirow[t]{2}{*}{ Male } & $6 / 84.4$ & $2 / 41$ & $1 / 5.8$ & $1 / 5.6$ \\
\hline & & $1.07 \pm 0.07$ & $2.05 \pm 0.17$ & $1.93 \pm 0.24$ & $1.87 \pm 0.07$ \\
\hline \multirow[t]{4}{*}{ Subadult } & \multirow[t]{2}{*}{ Female } & $1 / 0.40$ & $3 / 54.8$ & $3 / 18.6$ & $3 / 8.6$ \\
\hline & & $0.20 \pm 0.01$ & $0.98 \pm 0.08$ & $1.43 \pm 0.19$ & $1.08 \pm 0.10$ \\
\hline & \multirow[t]{2}{*}{ Male } & $7 / 66.8$ & $8 / 165.2$ & $6 / 23.6$ & $6 / 16.8$ \\
\hline & & $0.77 \pm 0.042$ & $1.41 \pm 0.07$ & $1.31 \pm 0.15$ & $1.30 \pm 0.13$ \\
\hline \multirow[t]{8}{*}{ Adult } & \multirow[t]{2}{*}{ Nonreproductive female } & $8 / 26.2$ & $11 / 83.2$ & $15 / 42.4$ & $15 / 34.2$ \\
\hline & & $0.61 \pm 0.05$ & $0.79 \pm 0.04$ & $1.06 \pm 0.06$ & $1.04 \pm 0.06$ \\
\hline & \multirow[t]{2}{*}{ Gestating female } & $23 / 209.6$ & $12 / 58.2$ & & \\
\hline & & $0.78 \pm 0.03$ & $1.19 \pm 0.06$ & & \\
\hline & \multirow[t]{2}{*}{ Lactating female } & & 21/194.6 & $10 / 29.4$ & $16 / 15.6$ \\
\hline & & & $0.76 \pm 0.03$ & $0.98 \pm 0.08$ & $0.82 \pm 0.06$ \\
\hline & \multirow[t]{2}{*}{ Male } & $11 / 82.2$ & $17 / 178.8$ & $16 / 38.6$ & $14 / 37.4$ \\
\hline & & $0.71 \pm 0.04$ & $0.77 \pm 0.03$ & $0.99 \pm 0.08$ & $1.04 \pm 0.07$ \\
\hline
\end{tabular}

day with a random starting point during the feeding bout, and these bite count rates are used as a measure of ingestion rate and feeding efficiency (Johnson and Bock 2004).

Analysis With the exception of the dietary diversity index, data were summarized per individual per day, generating a mixedlongitudinal data set of individual days. Generalized linear mixed models (GLMMs) were fit to the mixed-longitudinal data in the lme4 package in R 2.13 (Bolker et al. 2009; R Core Development Team 2011). In all models, individual animal identity was included as a random effect to control both for the repeated sampling of individuals and variability due to individual preferences. Much of the data presented are summarized as proportions of a total (e.g., proportion of time feeding). Logistic mixed models with a binomial distribution and logit link identity were fit to proportional data directly (Jaeger 2008; Warton and Hui 2011). The significance of the fixed factors (e.g., age and sex) was evaluated by comparing two nested models differing in the factor of interest with a likelihood ratio test of the two nested models $\left(\chi^{2}\right)$ (Lewis et al. 2011; Huchard et al. 2012). Tukey's post-hoc tests identified differences among factor level pairwise comparisons, typically age-sex levels. Mean dietary overlap of age-sex classes for the 2week block intervals was calculated using random effects of individual and social group. However, because of the high number of age-sex pairwise combinations, the significance levels of the post-hoc comparisons of dietary overlap index is highly autocorrelated and we therefore present the age-sex values without significance levels (Post et al. 1980). When no random effects were present (e.g., number of plants eaten by an age class), a general linear model (F) was fit to the data. Significant fluctuations in food availability are correlated with reproductive timing in ring-tailed lemurs (Sauther 1998). Considering this established relationship, dietary composition was analyzed within a given reproductive season. Significance for all tests was evaluated at $\alpha=0.05$, and means are presented with standard errors. 


\section{Results}

Seasonality in food availability Ring-tailed lemurs fed from 137 plant species from 55 families,and on six invertebrate species from four orders (O'Mara 2012). Food availability varied throughout the year, with peak FAI coinciding with maximum rainfall (Fig. 1). Young leaf flush, which began in September with the transition to the wet season, was the major contributor to food availability. The weaning of offspring (i.e., transition to juvenile 1) was timed to the period of maximum young leaf availability (January-February); availability dramatically decreased in March and into the dry season. Ripe fruit was at its peak availability at the end of the wet season and continues through the beginning of the dry season (March-September).

Early sex differences that continue to adulthood Most fruits and young leaves, which comprised the bulk of the ring-tailed lemur diet, are ingested in a single bite by all age categories (Sauther 1992). There were no sex effects on intake rate (bites/ min) when controlling for food type and species across all ages of ring-tailed lemurs $\left(\chi_{1}^{2}=1.151 ; p=0.283\right)$. This indicates that along with the lack of sexual size dimorphism in ring-tailed lemurs, comparisons of time spent feeding are adequate to test for sex differences in feeding within an age class. Infant 2 dedicate significantly more of their total time to feeding and foraging than all other age classes $\left(\chi_{3}^{2}=23.828\right.$, $p<0.001$; Fig. 2a), and there were no effects of sex or reproductive status at any age in the total amount of time that individuals spent feeding and foraging $\left(\chi_{3}^{2}=1.717, p=\right.$ $0.633)$. When tested as a main effect, there were no significant seasonal effects on the ratio of time spent feeding to time foraging $\left(\chi_{3}^{2}=2.475, p=0.480\right)$. However, reproductive season was included as a random effect along with individual identity to account for potential variation due to food availability. After weaning in juvenile 1, males had higher ratios of the time spent feeding relative to foraging than did females $\left(\chi_{13}^{2}=28.508, p=0.008\right.$; Fig. 2b). Nonreproductive females invested more time foraging than did males and gestating and lactating females (Fig. 2b), but there were no differences in ratio of time feeding to foraging among males and females that were gestating and lactating.

Sex and age differences in dietary diversity paralleled food availability. From juvenile 2, females had more diverse diets than males (Fig. 3). Juveniles and subadults of both sexes showed higher dietary diversity than adults, but the sex differences that were present in the juvenile 2 stage continued throughout adulthood, with females feeding on more diverse diets than males in seasons with lower food availability: Gestation and lactation seasons $\left(\chi_{13}^{2}=60.749, p<0.001\right.$; Fig. 3). As the availability of young leaves increased in the weaning and recovery seasons (Fig. 1), the differences between males and females disappeared in the immature age categories (except juvenile 2). Females in the recovery season again have more diverse diets than males (Fig. 3).

Dietary overlap was generally low both within and among most age-sex categories. Dietary overlap among age-sex categories was variable across the year and does not show a clear pattern of increasing or decreasing overlap throughout development (Fig. 4). $R$ values greater than 0.5 (red to dark red, Fig. 4) indicate significant levels of dietary overlap (Pianka 1973), with approximately $50 \%$ of the diet in both categories shared. Across the year, mean dietary overlap ranged from 0 (yellow) to 0.84 (dark red), with most dietary overlap scores of 0.2-0.4 (orange). Infants and juveniles had low dietary overlap with most other group members and tended to have highest overlap values with age-mates, subadults, and lactating females (Fig. 4). The highest dietary overlap was found during the recovery season, potentially due to the decrease in young leaf and overall food availability that presented lemurs fewer options.

Infants, juveniles, and subadults experienced higher rates of aggression directed at them while feeding and foraging than do adults $\left(\chi_{11}^{2}=98.609, p<0.001\right.$; Fig. 5a). Males received higher rates of aggression during feeding and foraging than females at most ages across the year $\left(\chi_{6}^{2}=46.612, p<0.001\right.$; Fig. 5a). Adult females were the primary aggressors in agonistic interactions, and this was not restricted to only the dominant individuals. Adult females were responsible for $78-99 \%$ of the aggressive interactions that age-sex categories received ( $\mathrm{F} / \mathrm{M}$ percent received from adult females: infant 1 , 78.8/92.0; infant 2, 83.3/83.8; juvenile $1,89.5 / 89.5$; juvenile 2, 79.9/91.1; subadult, 94.1/85.3; adult, 98.8/90.6). When the number of aggressive interactions that were directed at an individual was subtracted from those interactions initiated by a focal subject, adult females were the only age--sex class with positive values, indicating that they aggressed at others more often than they received aggression (Fig. 5b).

Sex differences in adults by reproductive season Apart from significant differences in dietary diversity, sex differences in adult feeding ecology were only present during the lactation season (see Appendix for seasonal model results), with significant sex differences in the percentage of time feeding on ripe fruit, mature leaves, young leaves, and flowers $\left(\chi_{9}^{2}=\right.$ 59.442, $p<0.001$; Table 2). During the lactation season, lactating females ingested a higher proportion of young leaves and ripe fruit than males or other females. Females that were gestating during this time (i.e., asynchronous females) ate a higher proportion of mature leaves and flowers than males and other females (Table 2).

Females, regardless of their reproductive status or season, fed from more plant species than did males, increasing their overall dietary diversity score $\left(\chi_{3}^{2}=36.689, p<0.001\right)$. The high dietary diversity and low dietary overlap of adults paralleled the FAI, with the lowest number of plant species 
Fig. 2 a The proportion of total observations (mean \pm SEM) spent feeding and foraging for females (orange) and male (blue) by age category. No sex differences are present, but significant differences among age categories are denoted by an asterisk. b Ratio of proportion of time feeding divided by proportion of time foraging for females (orange) and male (blue) by age category. Significant pairwise sex differences within age categories are denoted by an asterisk

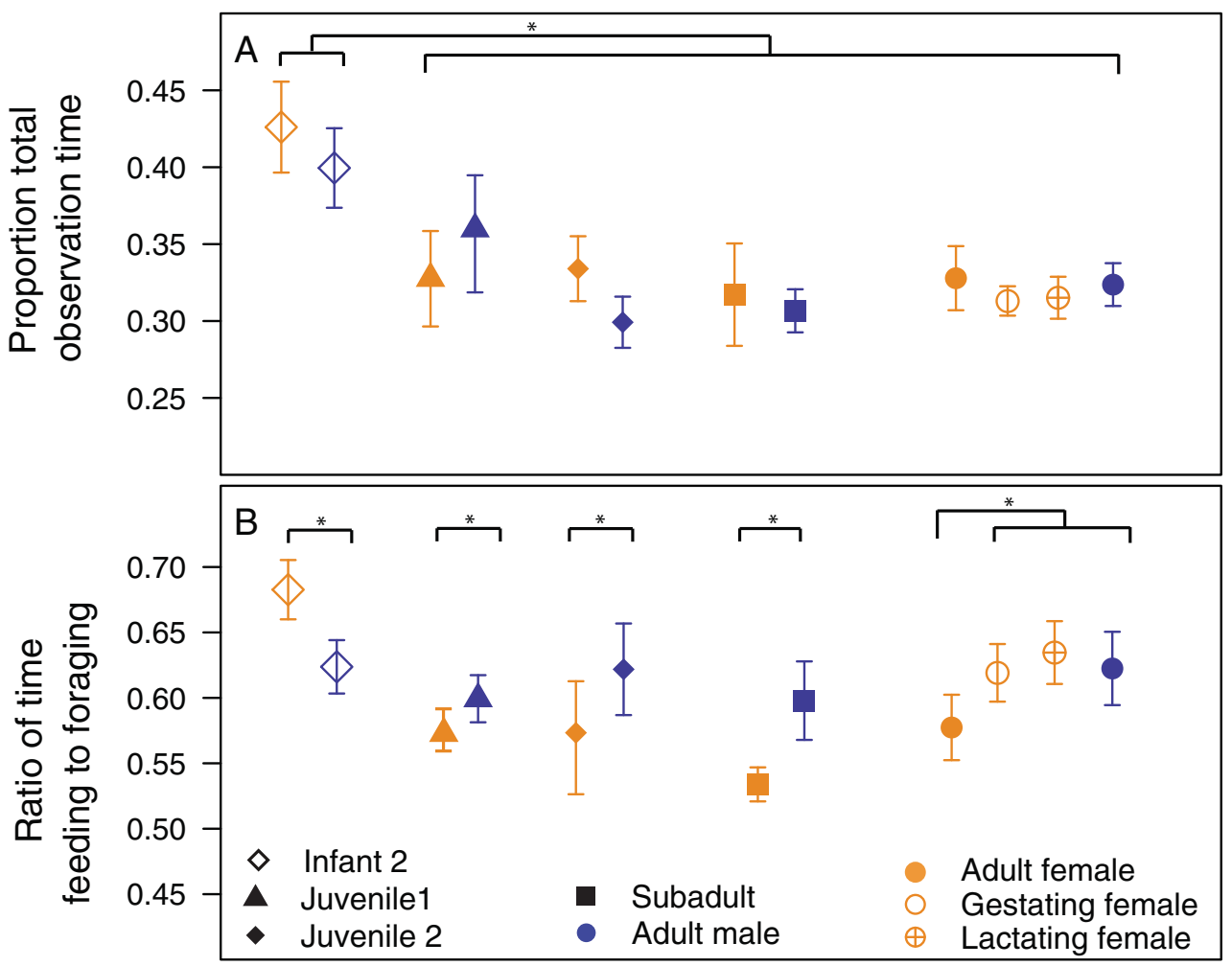

eaten per day during the gestation season and greatest number during the weaning season, when FAI was at its highest (gestation, 3.31 \pm 0.12 ; lactation, $4.29 \pm 0.10$; weaning, $4.98 \pm$ 0.22; recovery, $4.54 \pm 0.30$; Fig. 1 for FAI). Across all seasons, lactating and nonreproducing females fed from a greater number of plant species than do males or gestating females $\left(F_{3}\right.$, ${ }_{593}=5.44, p=0.001$; lactating females, $3.70 \pm 0.15$; nonreproductive females, $3.76 \pm 0.18$; gestating females, $3.02 \pm 0.15$; males, 3.35 \pm 0.13 ). During lactation, weaning, and recovery seasons, female reproductive stage did not impact dietary diversity (Fig. 3). The sex differences in dietary composition and diversity during lactation were accompanied by the lowest levels of dietary overlap (Fig. 4). Adult females and males have low to moderate dietary overlap across the year. Most age-sex categories show low overlap within themselves, although asynchronous adult females (e.g., gestating females
Fig. 3 Simpson's inverse dietary diversity index (mean \pm SEM) for females (orange) and males (blue) across age categories for solid food. Asterisks denote significant differences between sexes or among reproductive categories within an age category

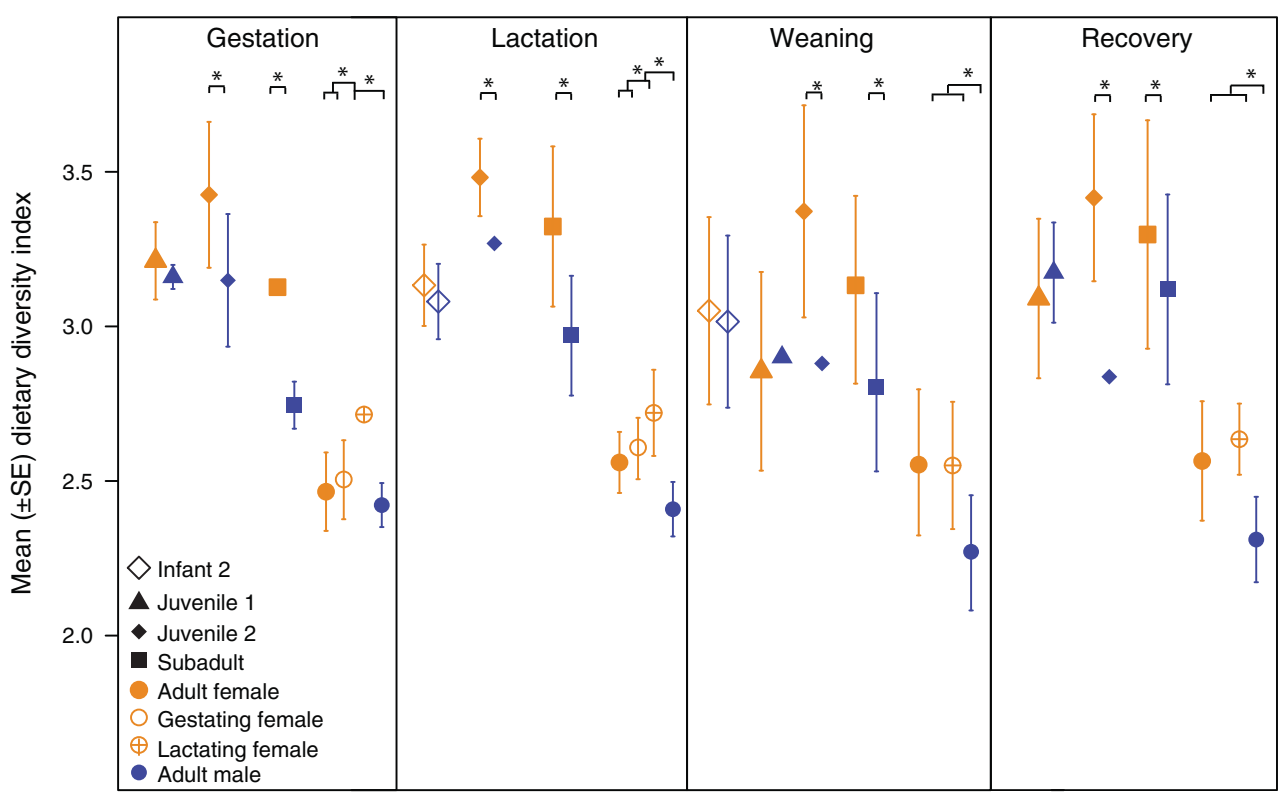


Fig. 4 Dietary overlap index $(R)$ among age sex categories within each season. Overlap values are represented by the increasing color gradient,and range from 0 (yellow) to 1 (dark red). Blanks cells indicate that no overlap index was calculated
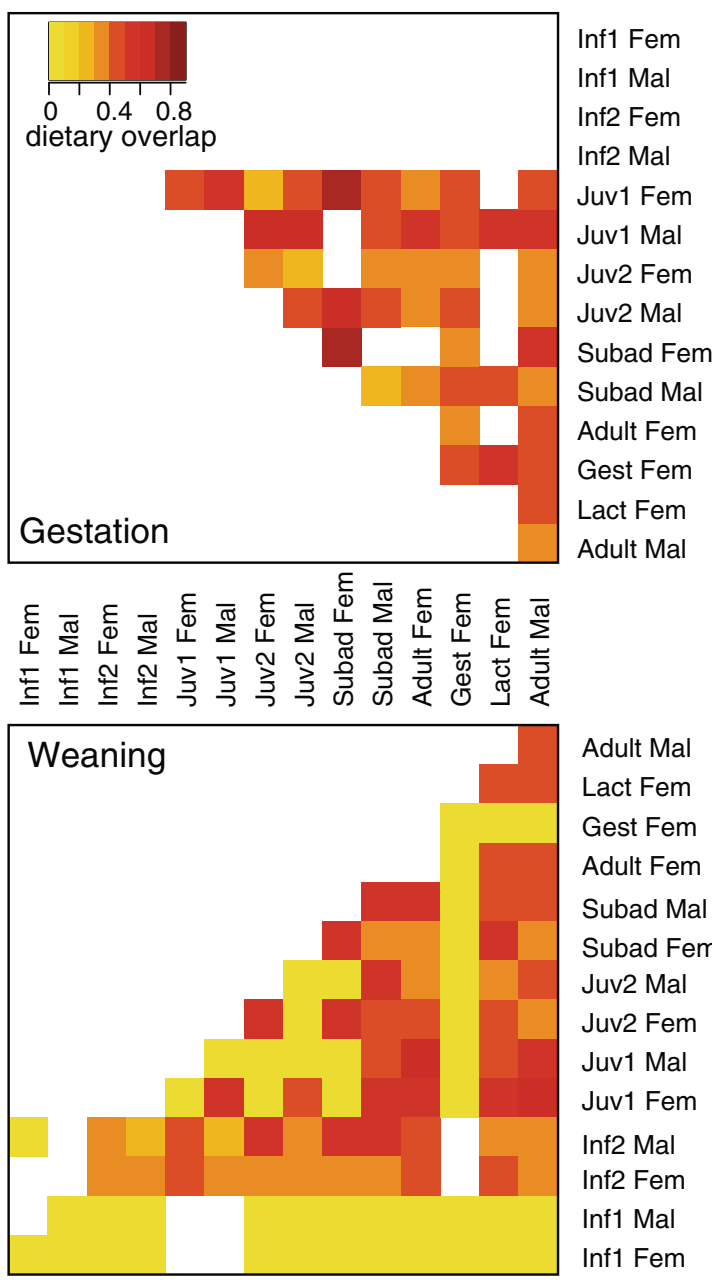
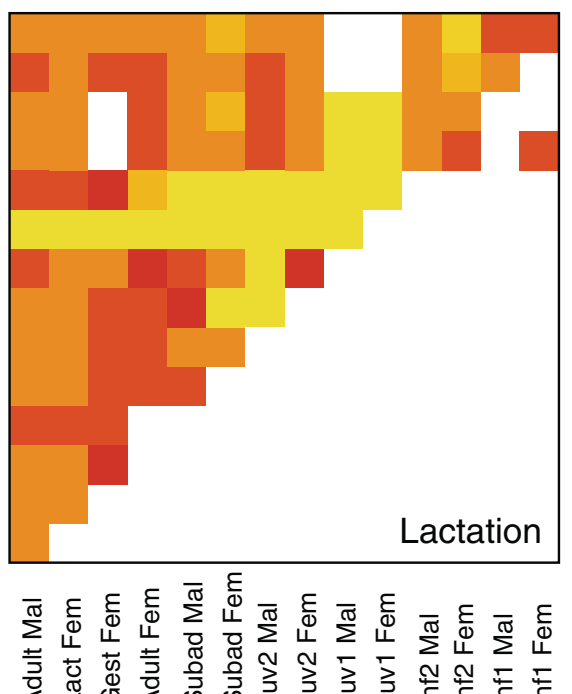

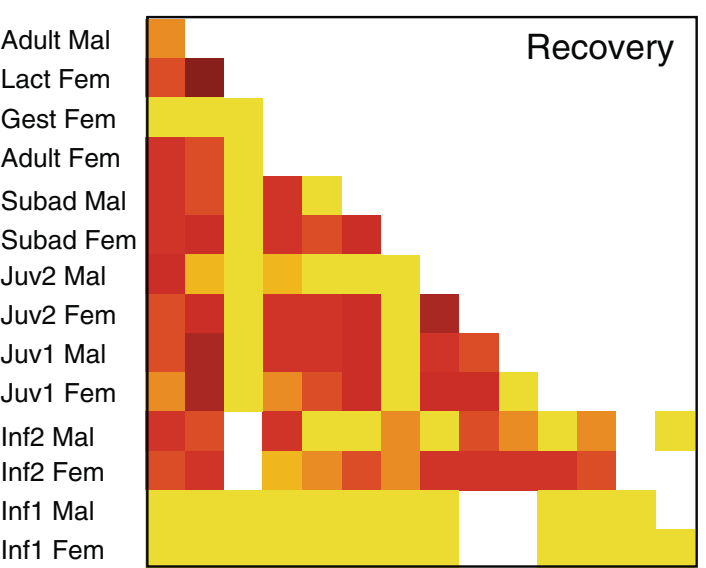

during lactation) had the highest overall observed dietary overlap scores with other asynchronous females in their groups.

\section{Discussion}

This ontogenetic study suggests that both costs of reproduction and resource partitioning are responsible for sex differences in ring-tailed lemur feeding ecology. Sex differences were found in adults during the most energetically costly period of reproduction when females were lactating and directly caring for offspring. This indicates that costs of reproduction structure the major ecological differences between adult females and males. However, dietary overlap among individuals within a group fluctuates throughout the year, but is generally low both within and among age-sex categories. When sex differences in feeding were present in immatures, they paralleled adult patterns, similar to what has been predicted for species with low or fluctuating sex differences in ecology (van Noordwijk et al. 1993). The low year-round dietary overlap and sex differences in dietary diversity that develop early in life and continue through adulthood indicate that some level of resource partitioning is present outside of reproductive activity.

Like other primate females (Gautier-Hion 1980; Ganzhorn 1989a; Rose 1994; Vasey 2002; McCabe and Fedigan 2007; Yamashita 2008; Ganzhorn et al. 2009), lactating ring-tailed lemurs shifted their dietary emphasis and fed more on young leaves and ripe fruit than did males and nonreproductive females. Female ring-tailed lemurs gestate during the period of lowest food availability, lactate during increasing food abundance, and wean their infants in the period of maximum food availability (Sauther 1991). The increase in both young leaves and ripe fruit in female diet potentially increased protein and energy consumption during lactation (Blaxter 1971; Pond 1977). However, this study cannot address if these sex differences in diet composition and diversity result in sex differences in nutritional intake, or if changes in female diet reflect correlated changes in protein and energy consumption. Some lemur species balance nutritional and energy intake across wet and dry seasons regardless of plant part composition (Curtis 2004; Yamashita 2008; Gould et al. 2011), 
Fig. 5 a Aggression received (mean \pm SEM) during feeding and foraging for females (orange) and males (blue) across age categories. b Sum of the aggression and individual directs towards others minus aggression directed at them. The dashed line shows the zero mark where aggression given equals aggression received. Asterisks in (a) and (b) denote significant differences between sexes or among reproductive stages within an age category

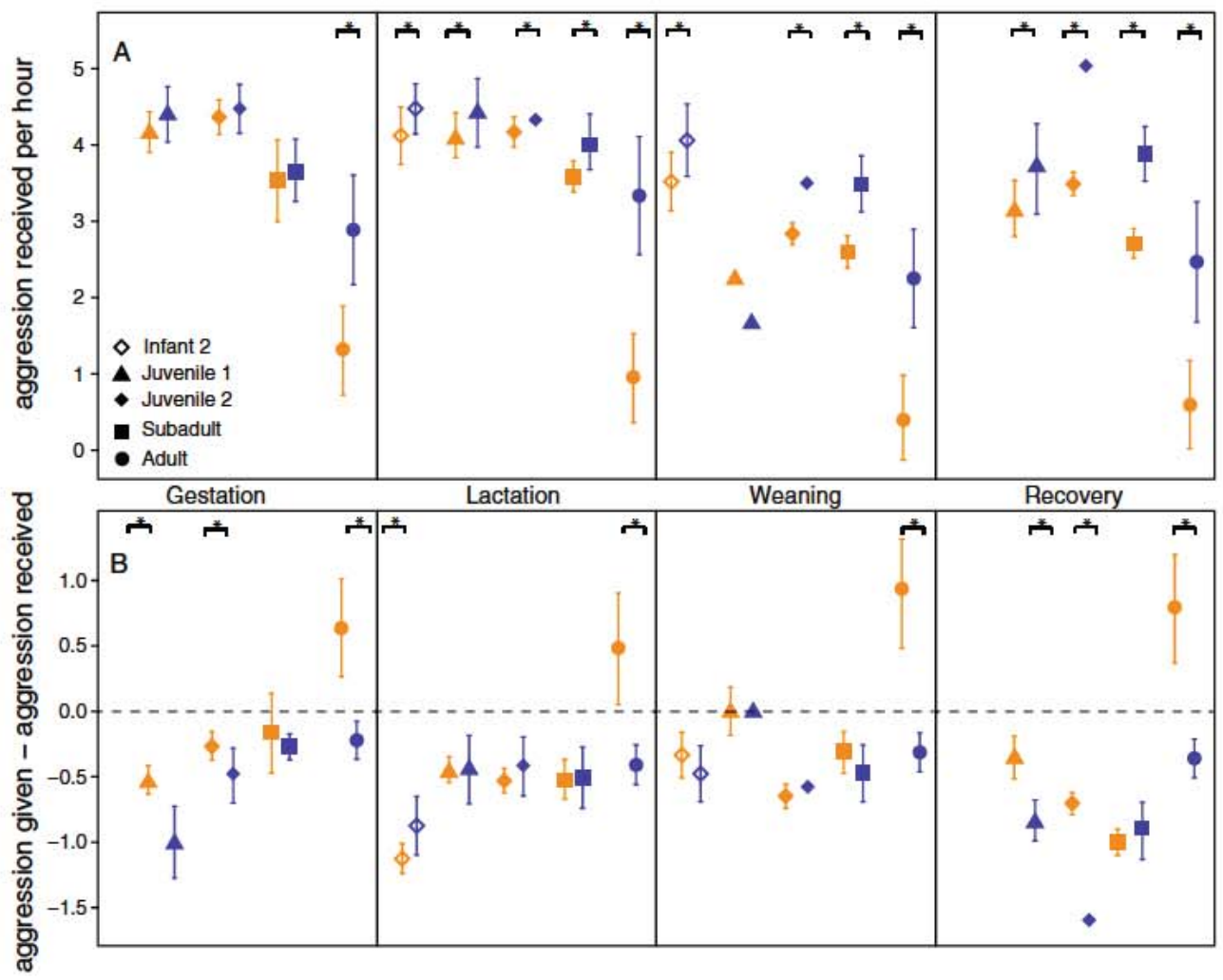

Table 2 Mean ( \pm SEM) proportion of a given plant part in the diet during the lactation season

\begin{tabular}{|c|c|c|c|c|c|c|c|}
\hline & Ripe fruit* & Unripe fruit & Mature leaf* & Young leaf* & Flowers* & Invertebrate & Soil, other \\
\hline \multicolumn{8}{|l|}{ Infant 1} \\
\hline Female & $0.95 \pm 0.10 \mathrm{a}$ & $0.19 \pm 0.21$ & $0.38 \pm 0.16 \mathrm{a}$ & $19.97 \pm 0.60 \mathrm{~b}$ & $0.94 \pm 0.96 \mathrm{a}$ & $7.50 \pm 0.11$ & $3.93 \pm 0.14$ \\
\hline Male & $0.44 \pm 0.11 \mathrm{a}$ & $0.51 \pm 0.22$ & $0.31 \pm 0.17 \mathrm{a}$ & $23.19 \pm 0.63 b$ & $0.99 \pm 1.00 \mathrm{a}$ & $5.40 \pm 0.16$ & $1.33 \pm 0.14$ \\
\hline \multicolumn{8}{|l|}{ Infant 2} \\
\hline Female & $12.89 \pm 0.13 b$ & $4.07 \pm 0.26$ & $0.67 \pm 0.21 \mathrm{a}$ & $33.22 \pm 0.74 \mathrm{~b}$ & $1.89 \pm 1.18 \mathrm{ab}$ & $0.31 \pm 0.14$ & $2.94 \pm 0.17$ \\
\hline Male & $7.12 \pm 0.12 a$ & $3.89 \pm 0.24$ & $0.21 \pm 0.19 \mathrm{a}$ & $28.66 \pm 0.70 b$ & $2.10 \pm 1.11 \mathrm{ab}$ & $0.38 \pm 0.13$ & $3.51 \pm 0.158$ \\
\hline \multicolumn{8}{|l|}{ Juvenile 1} \\
\hline Female & $9.89 \pm 0.29 b$ & $0.14 \pm 0.60$ & $12.19 \pm 0.47 c$ & $27.97 \pm 1.72 b$ & $38.62 \pm 2.73 \mathrm{c}$ & $0.00 \pm 0.32$ & $2.10 \pm 0.38$ \\
\hline Male & $0.32 \pm 0.55 a$ & $0.78 \pm 1.15$ & $4.30 \pm 0.90 b$ & $2.67 \pm 3.30 \mathrm{a}$ & $91.66 \pm 5.23 \mathrm{~d}$ & $0.00 \pm 0.61$ & $0.27 \pm 0.75$ \\
\hline \multicolumn{8}{|l|}{ Juvenile 2} \\
\hline Female & $10.21 \pm 0.11 \mathrm{~b}$ & $3.83 \pm 0.22$ & $2.44 \pm 0.17 \mathrm{~b}$ & $60.89 \pm 0.64 c$ & $5.72 \pm 1.01 \mathrm{~b}$ & $8.23 \pm 0.12$ & $3.63 \pm 0.14$ \\
\hline Male & $13.85 \pm 0.21 \mathrm{~b}$ & $2.67 \pm 0.45$ & $0.18 \pm 0.35 \mathrm{a}$ & $64.68 \pm 1.28 \mathrm{c}$ & $8.18 \pm 2.03 b$ & $3.88 \pm 0.24$ & $1.58 \pm 0.29$ \\
\hline \multicolumn{8}{|l|}{ Subadult } \\
\hline Female & $14.60 \pm 0.13 b$ & $2.92 \pm 0.27$ & $1.94 \pm 0.21 \mathrm{~b}$ & $50.27 \pm 0.77 \mathrm{c}$ & $8.78 \pm 1.22 \mathrm{~b}$ & $8.28 \pm 0.14$ & $5.93 \pm 0.17$ \\
\hline Male & $7.14 \pm 0.09 a$ & $6.73 \pm 0.19$ & $2.81 \pm 0.15 b$ & $58.75 \pm 0.53 \mathrm{c}$ & $10.71 \pm 0.85 \mathrm{c}$ & $5.52 \pm 0.10$ & $4.87 \pm 0.12$ \\
\hline \multicolumn{8}{|l|}{ Adult } \\
\hline Female & $8.81 \pm 0.10 a$ & $4.47 \pm 0.21$ & $1.93 \pm 0.16 b$ & $65.77 \pm 0.59 c$ & $2.13 \pm 0.94 b c$ & $2.10 \pm 0.11$ & $10.95 \pm 0.13$ \\
\hline Gestating Female & $10.28 \pm 0.14 b$ & $0.76 \pm 0.29$ & $10.44 \pm 0.23 c$ & $33.61 \pm 0.83 c$ & $31.05 \pm 1.32 d$ & $2.07 \pm 0.15$ & $5.09 \pm 0.19$ \\
\hline Lactating Female & $11.03 \pm 0.06 \mathrm{~b}$ & $6.66 \pm 0.13$ & $1.38 \pm 0.10 a$ & $55.80 \pm 0.36 c$ & $7.07 \pm 0.56 c$ & $6.39 \pm 0.07$ & $6.36 \pm 0.08$ \\
\hline Male & $6.42 \pm 0.06 a$ & $6.42 \pm 0.13$ & $2.30 \pm 0.11 b$ & $56.54 \pm 0.38 c$ & $9.41 \pm 0.61 c$ & $5.15 \pm 0.07$ & $5.35 \pm 0.09$ \\
\hline
\end{tabular}

Sex differences within an age category are in italics. Lowercase letters within a column join age sex categories with similar mean consumption of a plant parts

${ }^{*} p<0.001$, significant effects of age sex class 
whereas others go into nutritional deficits during lean season (Irwin et al. 2014). It is unknown, however, if the nutritional composition of these lemur diets varies by sex or by reproductive state (Ganzhorn 1988; Curtis 2004; Yamashita 2008; Irwin et al. 2014). In another population of ring-tailed lemurs, there are no sex differences in dietary composition, energy, or crude protein ingested during the gestation season (Gould et al. 2011), but it is unknown if the subsequent sex differences later in reproduction alter this relationship. Nutritional information is not available from the 137 foods eaten by lemurs in this study, but there is a high correlation in categorical lemur foods (e.g., young leaves, ripe fruit, and flowers), and their nutritional content such that substitution of food categories cannot yield balanced diets unless substituted in large quantities (Ganzhorn 1988, 1989b; Curtis 2004).

In nonhuman primate species with male dominance, males typically invest less total time feeding and foraging than females (Wrangham and Smuts 1980; Boinski 1988; van Noordwijk et al. 1993; Rose 1994; Kamilar and Pokempner 2008), and their priority of access to resources allows them to feed on desired foods while freeing more time to secure future reproductive opportunities (Clutton-Brock 1977a). Primate species with low levels of sex-biased dominance or female-dominant social structures do not reflect this pattern. Female dominance found in lemur species is closely tied to priority of access to food resources and is hypothesized to be a response to reproduction in an uncertain resource environment (Young et al. 1990; Wright 1999; Dewar and Richard 2007). However, sex differences in multiple aspects of feeding are not only confined to species with large groups and strong female dominance but are also found in species that live in small groups where female dominance is low or absent (Overdorff 1991). Sex differences in dietary composition are present both in lemur species where males and females dedicate equal proportions of time to feeding and foraging (Richard 1978; Hemingway 1999); this study) and in those where sex differences in feeding time are present throughout the year (Overdorff 1996; Hemingway 1999; Grassi 2002; Vasey 2002). Even when there is an absence of sex and age differences in the consumption of broad food categories, ring-tailed lemurs showed low levels of dietary overlap within a group and significant differences in dietary diversity. These indicate that while they may feed on the same plant part during many times of the year, males and females, as well as young and adult lemurs may choose different species to fulfill their dietary needs which can result in few differences in the nutritional content of the diet (Gould et al. 2011).

Male ring-tailed lemurs appear to be either more efficient at finding food, less selective at what they eat, or must feed on what is easily available; however, this study cannot directly test among these possibilities. Males are significant competitors with females for food (Sauther 1993), but can be excluded from a feeding site by any female, and are reluctant to leave feeding patches unless displaced (Sauther 1994). It may be necessary for males to feed quickly before a female removes them from a feeding site, and these males may race ahead of their social group to feed quickly before arrival of the group (Sauther 1994). Females did not alter the total amount of time spent feeding and foraging seasonally, but their relative efficiency fluctuated with reproductive status. When females are not gestating or lactating, it is possible that they are under lower energetic constraints and could be less efficient but more selective in food choice. There were no differences among gestating and lactating females and males in their relative time feeding and foraging. This suggests that females in these stages of reproduction are more efficient at finding food than at other times of the year, likely because elevated costs of reproduction necessitate efficient ingestion, likely because nursing, handling, and raising offspring limits female potential foraging time.

If nutritional and energetic intake is consistent across seasons (Yamashita 2008), then resource partitioning may provide additional ecological space to allow females to quickly recover and prepare for the next reproductive season. The body condition of lactating females decreased as their offspring grew and showed visible weight loss and dull and thinning coats (O’Mara, personal observation; Pereira 1993; Jolly 2008). Despite this visible energetic drain, females must obtain a high enough body condition to allow annual reproduction typical of ring-tailed lemurs (Sauther 1991; Koyama et al. 2001). Sex differences in diet composition during lactation may not be sufficient to provide an ecological buffer that allows females to recover from their current offspring in preparation for the next mating cycle. Low dietary overlap among individuals within a group and the early sex differences in dietary diversity that continue through adulthood may provide this additional ecological space. Dietary overlap both within and among age-sex categories was low but is similar to overlap found in baboons, which also feed from eclectic diets based on young leaves and fruit (Post et al. 1980). This low level of overlap corresponds with sex differences in dietary diversity that began in juvenility and continued to adulthood. These early and persistent differences in overlap and diversity are unlike sex differences in monkey species, where sex differences fluctuate more heavily throughout development (Post et al. 1980; Harrison 1983; van Noordwijk et al. 1993). However, like many other primates, female ringtailed lemur diets are more diverse (Gautier-Hion 1980; Boinski 1988; Grassi 2002), which may be a general strategy to meet fluctuating energetic and nutritional needs while minimizing fiber intake and exposure to secondary compounds (Ganzhorn 1989b; Yamashita 2008).

While sex differences in dietary diversity are found early in juvenility in some primates (van Noordwijk et al. 1993), it has been unclear what the role of early dietary diversity is and has been hypothesized that these differences have little functional significance (van Noordwijk et al. 1993). High diversity diets 
that have low overlap with some adults may be an ecologically risk averse strategy when faced with larger, stronger, and more dominant competitors (Janson and van Schaik 1993). Juveniles often show higher dietary diversity and motivation to explore than adults (Hanya 2003; Fragaszy and Visalberghi 2004). Juvenile ring-tailed lemurs are the first to try new foods, and consistent with their sex-biased dominance relationships, young females are bolder than males (Kappeler 1987). In some monkeys, juveniles learn sex differences in feeding through biased associations with group members of the same sex (Agostini and Visalberghi 2005; Rapaport and Brown 2008), particularly when the sex differences are stable throughout the year. In these cases, immatures require long associations with older males to learn sex-typical foraging techniques (Pereira 1988; Agostini and Visalberghi 2005). Social learning and observation of other individuals during these sex-biased associations may then be the primary way that these species acquire sex-typical diets.

However, sex differences in ring-tailed lemurs are not learned through same-sex modeling (O'Mara and Hickey 2012), and it is likely a result of the inconsistent levels of sex differences throughout the year that precludes such associations. In a previous study, we found that infant and juvenile ring-tailed lemurs did not preferentially associate with samesex group members during feeding and foraging but synchronized their feeding with any older group member close to them (O'Mara and Hickey 2012), which is a more generalized tactic than the close mother-offspring association found in brown lemurs (Tarnaud 2004, 2008). This indiscriminate local enhancement may be more advantageous in a species with low and fluctuating levels of sex differential feeding, as well as explain why juveniles have the highest dietary diversity within a social group. Simultaneous feeding with adults of both sexes allows them to sample the full range of dietary options. However, males have more aggression directed at them, which may decrease their learning opportunities (Kendal et al. 2010) and limit the potential food items that they can ingest. Sex differences in dietary diversity and diet composition are then likely a consequence of female dominance and competitive exclusion, rather than more monkey-like model of social learning from same-sex adult partners (O'Mara and Hickey 2012).

Our results show that sex differences in ecology begin early in life, and it is possible that these initial differences between males and females place them on separate behavioral trajectories toward adulthood. Sex differences in ring-tailed lemur feeding ecology are correlated with increased costs to females during lactation, with low degrees of resource partitioning throughout the year through low dietary overlap and sex differences in dietary diversity that develop in juvenility. Importantly, there are long-term consequences of sex differences in diet in ring-tailed lemurs. Males exhibit faster and more extreme dental wear than females (Cuozzo et al. 2014), likely due to feeding more heavily on highly abrasive T. indica fruit. Male ring-tailed lemurs have higher ectoparasite loads, lower fat reserve levels, and higher incidence of dermatitis that may be linked to nutritional deficits, particularly in the season after infants are weaned (Sauther et al. 2006), but do not show higher fecal glucocorticoid levels at this time despite their low rank (O'Mara, unpublished data). This study highlights the importance of incorporating developmental perspective into understanding how and when adult behaviors appear. Future explorations of the ontogeny of both ecological and behavioral sex differences and underlying physiological mechanisms will help us understand how sex, behavior, and ecology interact to shape the diversity of vertebrate social systems.

Acknowledgments The authors would like to thank Ayden Sherritt, Paul Stephen, and Andy Fogel for their help with data collection. The authors thank Madagascar National Parks, the Ministére des Eaux et Forêt, and ESSA Forêt Université d'Antananarivo for research permis sion, and to the staff at Beza Mahafaly and MICET for facilitating logistics. Michelle Sauther, Frank Cuozzo, Jacky Antho, Stephanie Mer edith, Andry Randrianandrasana, Jeannin Ranaivonasy, Benjamin Andriamihaja, and the members of the Beza Mahafaly Ecological Mon itoring Team were all supportive of the fieldwork, as were Alison Richard and Robert Dewar. Leanne Nash, Kate Ihle, Meg Crofoot, Stephanie Meredith, and two anonymous reviewers greatly improved this manu script. This work was supported by the National Science Foundation DDIG (BCS 0851761), the J. William Fulbright Foundation, Sigma Xi and its ASU chapter, the ASU Graduate and Professional Students Association, and the ASU School of Human Evolution and Social Change.

Ethical standards All methods conformed to the Guidelines for the Use of Animals in Research of the Animal Behavior Society and were approved by the IACUC at Arizona State University ( 08 983R) and by Madagascar National Parks (135/07; 257/09).

\section{References}

Agostini I, Visalberghi E (2005) Social influences on the acquisition of sex typical foraging patterns by juveniles in a group of wild tufted capuchin monkeys (Cebus nigritus). Am J Primatol 65:335 351

Altmann J (1974) Observational study of behavior: sampling methods. Behaviour 49:227 265

Altmann SA (1991) Diet of yearling female primates (Papio cynocephalus) predicts lifetime fitness. Proc Natl Acad Sci U S A 88:420 423

Altmann SA (1998) Foraging for survival: yearling baboons in Africa. University of Chicago Press, Chicago

Altmann J, Samuels A (1992) Costs of maternal care: infant carrying in baboons. Behav Ecol Sociobiol 29:391 398

Barton RA, Whiten A (1993) Feeding competition among female olive baboons, Papio anubis. Anim Behav 46:777 789

Bean A (1999) Ecology of sex differences in great ape foraging. In: Lee PC (ed) Comparative primate socioecology. Cambridge University Press, Cambridge, pp 339362

Beck CA, Iverson SJ, Bowen WD (2005) Blubber fatty acids of gray seals reveal sex differences in the diet of a size dimorphic marine carni vore. Can J Zool 83:377 388 
Begon M, Harper J, Townsend C (1996) Ecology. Blackwell Sciences, Oxford

Bezanson M (2009) Life history and locomotion in Cebus capucinus and Alouatta palliata. Am J Phys Anthropol 140:508 517

Blaxter K (1971) The comparative biology of lactation. Lactation 467: 5169

Boinski S (1988) Sex differences in the foraging behavior of squirrel monkeys in a seasonal habitat. Behav Ecol Sociobiol 23:177 186

Bolker B, Brooks M, Clark C, Geange S, Poulsen J, Stevens M, White J (2009) Generalized linear mixed models: a practical guide for ecol ogy and evolution. Trends Ecol Evol 24:127 135

Bolnick DI, Yang LH, Fordyce JA, Davis JM, Svanbäck R (2002) Measuring individual level resource specialization. Ecology 83: 29362941

Bolnick DI, Svanbäck R, Fordyce JA, Yang LH, Davis JM, Hulsey CD, Forister ML (2003) The ecology of individuals: incidence and implications of individual specialization. Am Nat 161:1 28

Bolnick DI, Amarasekare P, Araújo MS, Bürger R, Levine JM, Novak M, Rudolf VHW, Schreiber SJ, Urban MC, Vasseur DA (2011) Why intraspecific trait variation matters in community ecology. Trends Ecol Evol 26:183 192

Bonanni R, Cafazzo S, Fantini C, Pontier D, Natoli E (2007) Feeding order in an urban feral domestic cat colony: relationship to domi nance rank, sex and age. Anim Behav 74:1369 1379

Clarke J, Manly B, Kerry K, Gardner H, Franchi E, Corsolini S, Focardi S (1998) Sex differences in Adélie penguin foraging strategies. Polar Biol 20:248 258

Clutton Brock TH (1977a) Some aspects of intraspecific variation in feeding and ranging behaviour in primates. In: Clutton Brock TH (ed) Primate ecology: studies of feeding and ranging behaviour in lemurs, monkeys, and apes. Academic, London, pp 539556

Clutton Brock TH (1977b) Species differences in feeding and ranging behaviour in primates. In: Clutton Brock TH (ed) Primate ecology: studies of feeding and ranging behaviour in lemurs, monkeys, and apes. Academic, London, pp 557584

Clutton Brock TH, Albon SD, Guinness FE (1989) Fitness costs of gestation and lactation in wild mammals. Nature 337:260 262

Coelho AM, Bramblett CA (1981) Interobserver agreement on a molec ular ethogram of the genus Papio. Anim Behav 29:443 448

R Core Development Team (2011) R: a language and environment for statistical computing. R Foundation for Statistical Computing, www.r project.org

Cuozzo F, Head B, Sauther M, Ungar P, O’Mara MT (2014) Sex and habitat as a source of dental wear variation early in life among known aged wild ring tailed lemurs (Lemur catta). Am J Primatol (in press)

Curtis DJ (2004) Diet and nutrition in wild mongoose lemurs (Eulemur mongoz) and their implications for the evolution of female domi nance and small group size in lemurs. Am J Phys Anthropol 124: 234247

Dewar R, Richard A (2007) Evolution in the hypervariable environment of Madagascar. Proc Natl Acad Sci U S A 104:13723 13727

Ebenman B (1988) Competition between age classes and population dynamics. J Theor Biol 131:389 400

Fleagle JG, Mittermeier RA (1980) Locomotor behavior, body size, and comparative ecology of seven Surinam monkeys. Am J Phys Anthropol 52:301 314

Fragaszy D (1990) Sex and age differences in the organization of behav ior in wedge capped capuchins, Cebus olivaceus. Behav Ecol 1:81 94

Fragaszy D, Visalberghi E (2004) Socially biased learning in monkeys. Learn Behav 32:24 35

Ganzhorn J (1988) Food partitioning among Malagasy primates. Oecologia 75:436 450

Ganzhorn J (1989a) Niche separation of seven lemur species in the eastern rainforest of Madagascar. Oecologia 79:279 286
Ganzhorn J (1989b) Primate species separation in relation to secondary plant chemicals. Hum Evol 4:125 132

Ganzhorn J, Arrigo Nelson S, Boinski S, Bollen A, Carrai V et al (2009) Possible fruit protein effects on primate communities in Madagascar and the neotropics. PLoS One 4:e8253

Gautier Hion A (1980) Seasonal variations of diet related to species and sex in a community of Cercopithecus monkeys. J Anim Ecol 49: 237269

Godfrey LR, Jungers WL (2002) Quaternary fossil lemurs. In: Hartwig WC (ed) The primate fossil record. Cambridge University Press, Cambridge, pp 97122

Gould L (1990) The social development of free ranging infant Lemur catta at Berenty Reserve, Madagascar. Int J Primatol 11:297 318

Gould L, Power ML, Ellwanger N, Rambeloarivony H (2011) Feeding behavior and nutrient intake in spiny forest dwelling ring tailed lemurs (Lemur catta) during early gestation and early to mid lactation periods: compensating in a harsh environment. Am J Phys Anthropol 145:469 179

Grassi C (2002) Sex differences in feeding, height, and space use in Hapalemur griseus. Int J Primatol 23:677 693

Gunst N, Boinski S, Fragaszy D (2008) Acquisition of foraging compe tence in wild brown capuchins (Cebus apella), with special reference to conspecifics' foraging artefacts as an indirect social influence. Behaviour 145:195 229

Gunst N, Leca J B, Boinski S, Fragaszy D (2010) The ontogeny of handling hard to process food in wild brown capuchins (Cebus apella apella): evidence from foraging on the fruit of Maximiliana maripa. Am J Primatol 72:960 973

Hanya G (2003) Age differences in food intake and dietary selection of wild male Japanese macaques. Primates 44:333 339

Harrison M (1983) Age and sex differences in the diet and feeding strategies of the green monkey, Cercopithecus sabaeus. Anim Behav 31:969 977

Hemingway CA (1999) Time budgets and foraging in a Malagasy pri mate: do sex differences reflect reproductive condition and female dominance? Behav Ecol Sociobiol 45:311 322

Hill MO (1973) Diversity and evenness: a unifying notation and its consequences. Ecology 54:427 432

Holmes RT (1986) Foraging patterns of forest birds: male female differ ences. Wilson Bull 98:196 213

Huchard E, Canale C, Le GC, Perret M, Henry P, Kappeler P (2012) Convenience polyandry or convenience polygyny? Costly sex under female control in a promiscuous primate. Proc R Soc Lond B 279(1732):1371 1379

Irwin M (2008) Feeding ecology of Propithecus diadema in forest fragments and continuous forest. Int J Primatol 29:95 115

Irwin M, Raharison J, Raubenheimer D, Chapman C, Rothman J (2014) Nutritional correlates of the "lean season": effects of seasonality and frugivory on the nutritional ecology of diademed sifakas. Am J Phys Anthropol 153:78 91

Jaeger T (2008) Categorical data analysis: away from ANOVAs (trans formation or not) and towards logit mixed models. J Mem Lang 59: 434446

Janson CH, van Schaik CP (1993) Ecological risk aversion in juvenile primates: slow and steady wins the race. In: Pereira ME, Fairbanks LA (eds) Juvenile primates: life history, development and behavior. Oxford University Press, New York, pp 5774

Jarman PJ (1983) Mating system and sexual dimorphism in large terres trial mammalian herbivores. Biol Rev 58:485 520

Johnson SE, Bock J (2004) Trade offs in skill acquisition and time allocation among juvenile chacma baboons. Hum Nat 15:45 62

Jolly A (1984) The puzzle of female feeding priority. In: Small MF (ed) Female primates. Alan R. Liss, Inc., New York, pp 197215

Jolly A (2008) Coat condition of ringtailed lemurs, Lemur catta at Berenty reserve, Madagascar: I. Differences by age, sex, density and tourism, 1996 2006. Am J Primatol 
Jolly A, Dobson A, Rasamimanana H, Walker J, O'Connor S, Solberg M, Perel V (2002) Demography of Lemur catta at Berenty reserve, Madagascar: effects of troop size, habitat and rainfall. Int J Primatol 23:327 353

Kamilar J, Pokempner A (2008) Does body mass dimorphism increase male female dietary niche separation? A comparative study of primates. Behaviour 145:1211 1234

Kappeler PM (1987) The acquisition process of a novel behavior pattern in a group of ring tailed lemurs (Lemur catta). Primates 28:225 228

Kappeler PM (1990) Female dominance in Lemur catta: more than just female feeding priority? Folia Primatol 55:92 95

Kappeler PM (1996) Causes and consequences of life history variation among strepsirhine primates. Am Nat 148:868 891

Kendal RL, Custance DM, Kendal JR, Vale G, Stoinski TS, Rakotomalala NL, Rasamimanana H (2010) Evidence for social learning in wild lemurs (Lemur catta). Learn Behav 38:220 234

Kleiber M (1965) Metabolic body size. In: Blaxter KL (ed) Energy metabolism. Proceedings. Academic Press, London, pp 427435

Koyama N, Nakamichi M, Oda R, Miyamoto N, Ichino S, Takahata Y (2001) A ten year summary of reproductive parameters for ring tailed lemurs at Berenty, Madagascar. Primates 42:1 14

Krüger O (2005) The evolution of reversed sexual size dimorphism in hawks, falcons and owls: a comparative study. Evol Ecol 19:467 486

Lawler R, Caswell H, Richard A, Ratsirarson J, Dewar R, Schwartz M (2009) Demography of Verreaux's sifaka in a stochastic rainfall environment. Oecologia 161:491 504

Leigh SR, Terranova CJ (1998) Comparative perspectives on bimaturism, ontogeny, and dimorphism in lemurid primates. Int J Primatol 19: 723749

Lewis S, Benvenuti S, Dall Antonia L, Griffiths R, Money L, Sherratt T, Wanless S, Hamer K (2002) Sex specific foraging behaviour in a monomorphic seabird. Proc R Soc Lond B 269:1687 1693

Lewis F, Butler A, Gilbert L (2011) A unified approach to model selection using the likelihood ratio test. Methods Ecol Evol 2:155 162

Lonsdorf EV (2005) Sex differences in the development of termite fishing skills in the wild chimpanzees, Pan troglodytes schweinfurthii, of Gombe National Park, Tanzania. Anim Behav $70: 673683$

Lonsdorf EV, Eberly LE, Pusey AE (2004) Sex differences in learning in chimpanzees. Nature 428:715 716

Mccabe G, Fedigan L (2007) Effects of reproductive status on energy intake, ingestion rates, and dietary composition of female Cebus capucinus at Santa Rosa, Costa Rica. Int J Primatol 28:837 851

Mcgraw WS (1998) Posture and support use of old world monkeys (Cercopithecidae): the influence of foraging strategies, activity pat terns, and the spatial distribution of preferred food items. Am J Primatol 46:229 250

Ménard N, Vallet D (1986) Le régime alimentaire de Macaca sylvanus dans differents habitats d'Algerie. II. Régime en foret semper virente et sur les sommets rocheux. Terre Vie Rev Ecol A 41:173 192

Michels AM (1998) Sex differences in food acquisition and aggression in captive common marmosets (Callithrix jacchus). Primates 39:549 556

Nakagawa N (2000) Seasonal, sex, and interspecific differences in activ ity time budgets and diets of patas monkeys (Erythrocebus patas) and tantalus monkeys (Cercopithecus aethiops tantalus), living sympatrically in northern Cameroon. Primates 41:161 174

O'Mara MT (2012) Development of feeding in ring tailed lemurs. Dissertation, Arizona State University

O'Mara MT, Hickey C (2012) Social influences on the development of ringtailed lemur feeding ecology. Anim Behav 84:1547 1555

O'Mara MT, Gordon A, Catlett K, Terranova C, Schwartz G (2012) Growth and the development of sexual size dimorphism in lorises and galagos. Am J Phys Anthropol 147:11 20
Overdorff D (1991) Ecological correlates of social structure in two prosimian primates: Eulemur fulvus rufus and Eulemur rubriventer in Madagascar. Dissertation, Duke University

Overdorff DJ (1996) Ecological correlates to social structure in two lemur species in Madagascar. Am J Phys Anthropol 100:487 506

Overdorff D, Erhart E, Mutschler T (2005) Does female dominance facilitate feeding priority in black and white ruffed lemurs (Varecia variegata) in southeastern Madagascar? Am J Primatol $66: 722$

Pereira ME (1988) Effects of age and sex on intra group spacing behavior in juvenile savannah baboons, Papio cynocephalus cynocephalus. Anim Behav 36:184 204

Pereira ME (1993) Seasonal adjustment of growth rate and adult body weight in ring tailed lemurs. In: Kappeler PM, Ganzhorn JU (eds) Lemur social systems and their ecological basis. Plenum, New York, pp 205222

Pereira ME (1995) Development and social dominance among group living primates. Am J Primatol 37:143 175

Pereira ME, Kappeler PM (1997) Divergent systems of agonistic behav iour in lemurid primates. Behaviour 134:225 274

Pereira ME, Leigh SR (2003) Modes of primate development. In: Kappeler PM, Pereira ME (eds) Primate life histories and socioecology. University of Chicago Press, Chicago, pp 149176

Pianka ER (1973) The structure of lizard communities. Annu Rev Ecol Syst 4:53 74

Polis GA (1984) Age structure component of niche width and intraspe cific resource partitioning: can age groups function as ecological species? Am Nat 541564

Pond CM (1977) The significance of lactation in the evolution of mam mals. Evolution 31:177 199

Post DG, Hausfater G, Mccuskey SA (1980) Feeding behavior of yellow baboons (Papio cynocephalus): relationship to age, gender and dominance rank. Folia Primatol 34:170 195

Rapaport L, Brown G (2008) Social influences on foraging behavior in young nonhuman primates: learning what, where, and how to eat. Evol Anthropol 17:189 201

Richard AF (1978) Behavioral variation: case study of a Malagasy lemur. Bucknell University Press, Lewisburg

Rose LM (1994) Sex differences in diet and foraging behavior in white faced capuchins (Cebus capucinus). Int J Primatol 15:95 114

Ruckstuhl K (2007) Sexual segregation in vertebrates: proximate and ultimate causes. Integr Comp Biol 47:245 257

Ruckstuhl K, Neuhaus P (2002) Sexual segregation in ungulates: a comparative test of three hypotheses. Biol Rev 77:77 96

Sauther ML (1991) Reproductive behavior of free ranging Lemur catta at Beza Mahafaly special reserve, Madagascar. Am J Phys Anthropol $84: 463477$

Sauther ML (1992) The effect of reproductive state, social rank and group size on resource use among free ranging ringtailed lemurs (Lemur catta) of Madagascar. Dissertation, Washington University

Sauther ML (1993) Resource competition in wild populations of ringtailed lemurs (Lemur catta): implications for female dominance. In: Kappeler PM, Ganzhorn JU (eds) Lemur social systems and their ecological basis. Plenum, New York, pp 135152

Sauther ML (1994) Wild plant use by pregnant and lactating ringtailed lemurs, with implications for early hominid foraging. In: Etkin NL (ed) Eating on the wild side. The pharmacologic, ecologic, and social implications of using noncultigens. The University of Arizona Press, Tucson, pp 240256

Sauther ML (1998) Interplay of phenology and reproduction in ring tailed lemurs: implications for ring tailed lemur conservation. Folia Primatol 69:309 320

Sauther ML, Fish KD, Cuozzo FP, Miller DS, Hunter Ishikawa M, Culbertson H (2006) Patterns of health, disease, and behavior among wild ringtailed lemurs, Lemur catta: effects of habitat and sex. In: Jolly A, Sussman RW, Koyama N, Rasamimanana H (eds) 
Ringtailed Lemur biology: Lemur catta in Madagascar. Springer, New York, pp 313331

Schoener T (1986) Resource partitioning. In: Kilkkawa J, Anderson D (eds) Community ecology pattern and process. Blackwell Scientific, Boston, pp 91126

Smith J, Kolowski J, Graham K, Dawes S, Holekamp K (2008) Social and ecological determinants of fission fusion dynamics in the spot ted hyaena. Anim Behav 76:619 636

Stauss C, Bearhop S, Bodey T, Garthe S, Gunn C, Grecian W, Inger R, Knight M, Newton J, Patrick S (2012) Sex specific foraging behav iour in northern gannets Morus bassanus: incidence and implica tions. Mar Ecol Prog Ser 457:151

Steudel K (2000) The physiology and energetics of movement: effects on individuals and groups. In: Boinski S, Garber PA (eds) On the move: how and why animals travel in groups. University Chicago Press, Chicago, pp 923

Stone A (2007) Ecological risk aversion and foraging behaviors of juvenile squirrel monkeys (Saimiri sciureus). Ethology 113:782 792

Sussman RW (1977) Feeding behaviour of Lemur catta and Lemur fulvus. In: Clutton Brock TH (ed) Primate ecology: studies of feed ing and ranging behaviour in lemurs, monkeys and apes. Academic Press, New York, pp 136

Sussman RW, Rakotozafy A (1994) Plant diversity and structural analysis of a tropical dry forest in southwestern Madagascar. Biotropica 26: 241254

Sussman RW, Ratsirarson J (2006) Beza Mahafaly Special Reserve: a research site in southwestern Madagascar. In: Jolly A, Sussman RW, Koyama N, Rasamimanana H (eds) Ringtailed lemur biology: Lemur catta in Madagascar. Springer, New York, pp 4351

Tarnaud L (2004) Ontogeny of feeding behavior of Eulemur fulvus in the dry forest of mayotte. Int J Primatol 25:803 824

Tarnaud L (2008) Mother young feeding synchrony and early food selection differences in Eulemur fulvus. Int J Primatol 29:1687 1695

Terborgh J (1983) Five new world primates: a study in comparative ecology. Princeton University Press, Princeton
Tilden C, Oftedal O (1997) Milk composition reflects pattern of maternal care in prosimian primates. Am J Primatol 41:195 211

Trivers RL (1972) Parental investment and sexual selection. In: Campbell B (ed) Sexual selection and the descent of man 1871 1971. Aldine Publishing Company, Chicago, pp 136179

van de Waal E, Borgeaud C, Whiten A (2013) Potent social learning and conformity shape a wild primate's foraging decisions. Science 340 : 483485

van Noordwijk MA, Hemelrijk CK, Herremans LA, Sterck EH (1993) Spatial position and behavioural sex differences in juvenile long tailed macaques. In: Pereira ME, Fairbanks LA (eds) Juvenile pri mates: life history, development, and behavior. New York, Oxford, pp 7785

Vasey N (2002) Niche separation in Varecia variegata rubra and Eulemur fulvus albifrons: II. Intraspecific patterns. Am J Phys Anthropol 118: 169183

Wan Y, Quan R C, Ren G P, Wang L, Yc L, Liu X H, Zhu J G (2013) Niche divergence among sex and age classes in black and white snub nosed monkeys (Rhinopithecus bieti). Int J Primatol 34:946 956

Warton D, Hui F (2011) The arcsine is asinine: the analysis of proportions in ecology. Ecology 92:3 10

Watts DP (1988) Environmental influences on mountain gorilla time budgets. Am J Primatol 15:195 211

White F, Wood K (2007) Female feeding priority in bonobos, Pan paniscus, and the question of female dominance. Am J Primatol 69:837 850

Wrangham R, Smuts B (1980) Sex differences in the behavioural ecology of chimpanzees in the Gombe National Park, Tanzania. J Reprod Fertil Suppl 28:13 31

Wright PC (1999) Lemur traits and Madagascar ecology: coping with an island environment. Yearb Phys Anthropol 42:31 72

Yamashita N (2008) Chemical properties of the diets of two lemur species in southwestern Madagascar. Int J Primatol 29:339 364

Young AL, Richard AF, Aiello LC (1990) Female dominance and maternal investment in strepsirhine primates. Am Nat 135: 473488 